\begin{tabular}{|l|}
\hline 2. To: (Receiving Organization) \\
Distribution
\end{tabular}

3. From: (Originating Organization) Process Control

6. Design Authority/ Design Agent/Cog. Engr.:

K. D. Fowler
4. Related EDT No.:

$N / A$

7. Purchase Order No.:

$$
\text { N/A }
$$

9. Equip./Component No.: N/A

For release

11A. Design Basel ine Document? [] Yes No

$[X]$
$N / A$

13. Permit/Permit Application No.: $N / A$

14. Required Response Date: $04 / 26 / 99$

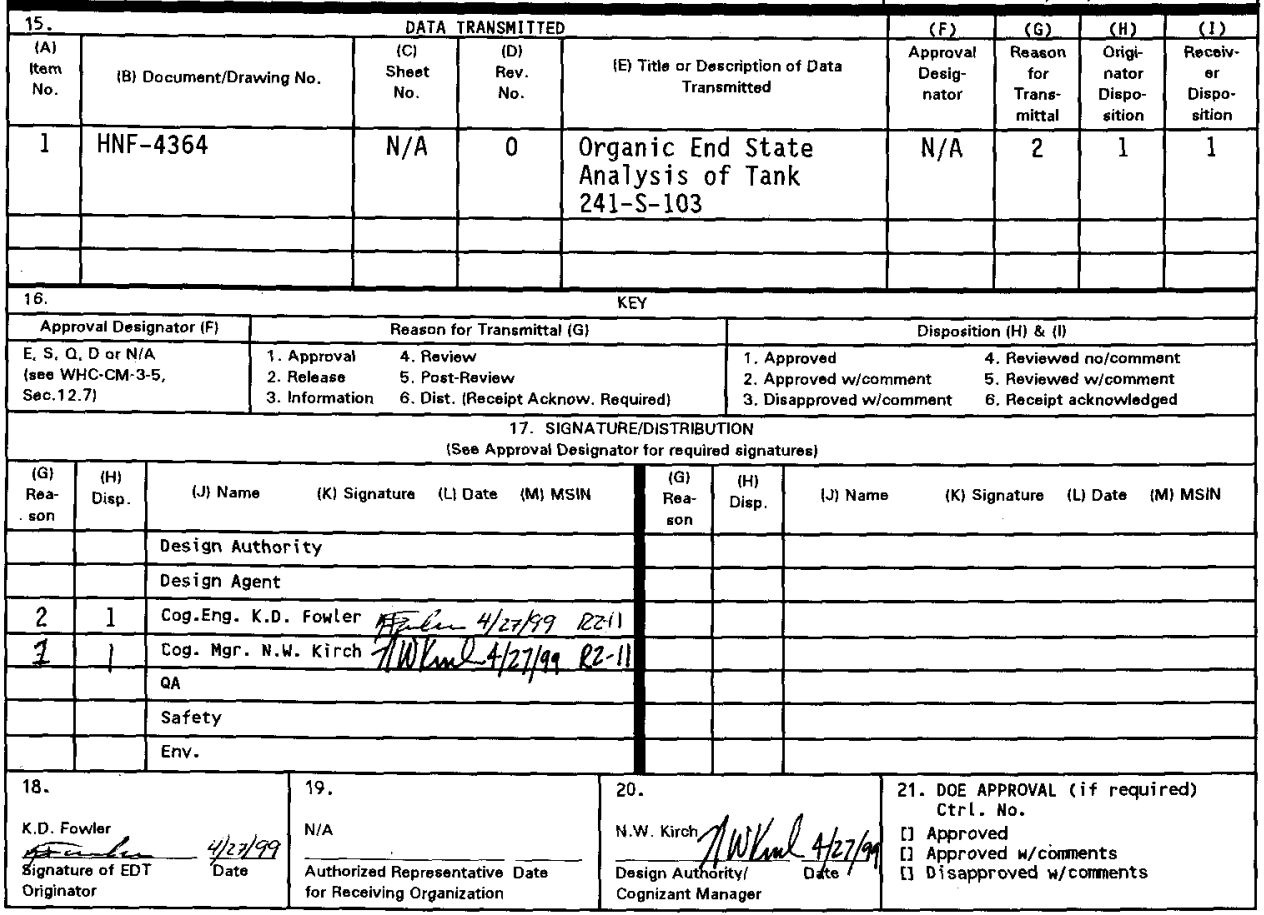

BD-7400-172-2 (05/96) GEF097 


\title{
Organic End State Analysis of Tank 241-S-103
}

\author{
K. D. Fowler \\ Lockheed Martin Hanford, Corp., Richland, WA 99352 \\ U.S. Department of Energy Contract DE-AC06-96RL 13200
}

$\begin{array}{lll}\text { EDT/ECN: } & \text { EDT-626580 } & \text { UC: } 2070 \\ \text { Org Code: } & 74 B 50 & \text { Charge Code: } 103371 \\ \text { B\&R Code: } & \text { EW } 3120074 & \text { Total Pages: } 7\end{array}$

Key Words: Organic, End State, Analysis, Tank 241-S-103, Tank \$-103, S-103, S Farm

Abstract: N/A

TRADEMARK DISCLAIMER. Reference herein to any specific cormercial product, process, or service by trade name, trademark, manufacturer, or otherwise, does not necessarily constitute or imply its endorsement, recontrendation, or favoring by the United States Government or any agency thereof or its contractors or subcontractors.

Printed in the United States of America. To obtain copies of this document, contact: Document Control Services, P.O. Box 950, Mailstop H6-08, Richland WA 99352, Phone (509) 372-2420; Fax (509) 376-4989.
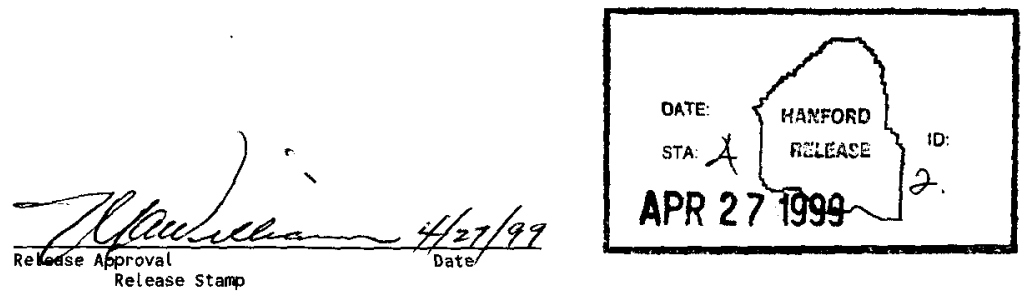

\section{Approved for Public Release}


HNF-4364, Rev. 0

\section{ORGANIC END STATE ANALYSIS OF TANK 241-S-103}

\subsection{PURPOSE}

This document provides a record of the organic end state analysis of tank 241-S-103.

\subsection{OPEN ITEMS}

There are no open items.

\subsection{DESCRIPTION OF TANK 241-S-103}

Tank 241-S-103 is one of twelve 22.9-meter (75-feet) diameter single-shell tanks in the 241-S Tank Farm in the 200 West Area of Hanford. This tank was built in 1951 and has a capacity of 2870 kiloliter $(\mathrm{kL})$ (758 kilogallon [kgal]).

According to Hanlon (1999), tank 241-S-103 currently contains $939 \mathrm{~kL}$ (248 kgal) of waste comprised of $840 \mathrm{~kL}$ (222 kgal) saltcake, $34 \mathrm{~kL}(9 \mathrm{kgal})$ sludge, and $64 \mathrm{~kL}$ (17 kgal) supernatant. Included in those volumes is $462 \mathrm{~kL}$ (122 kgal) drainable interstitial liquid. The pumpable volume is estimated at $416 \mathrm{~kL}$ (110 kgal). The waste is designated as double-shell slurry feed (DSSF). Tank 241-S-103 is not a Watch List tank. Tank $241-\mathrm{S}-103$ has not been declared as a leaker.

\subsection{METHOD OF ANALYSIS}

Analysis of tank 241-S-103 is per the methodology in HNF-SD-WM-PROC-021, Revision 2-A, Section 20.0, "End-State Organic Analysis Methodology (Single-Shell Tanks)," (Adams, 1999). Figure 1 shows the decision logic used to determine if a tank can be pumped. Information that provides the input to a decision block (criterion) is evaluated. If the preponderance of evidence (information) supports an answer of "Yes" to the decision block, pumping is allowed. If a decision block is answered "No," the logic proceeds to the next decision block and associated inputs. 
HNF-4364, Rev. 0

Figure 1. Logic To Determine Whether A Tank Can Be Pumped

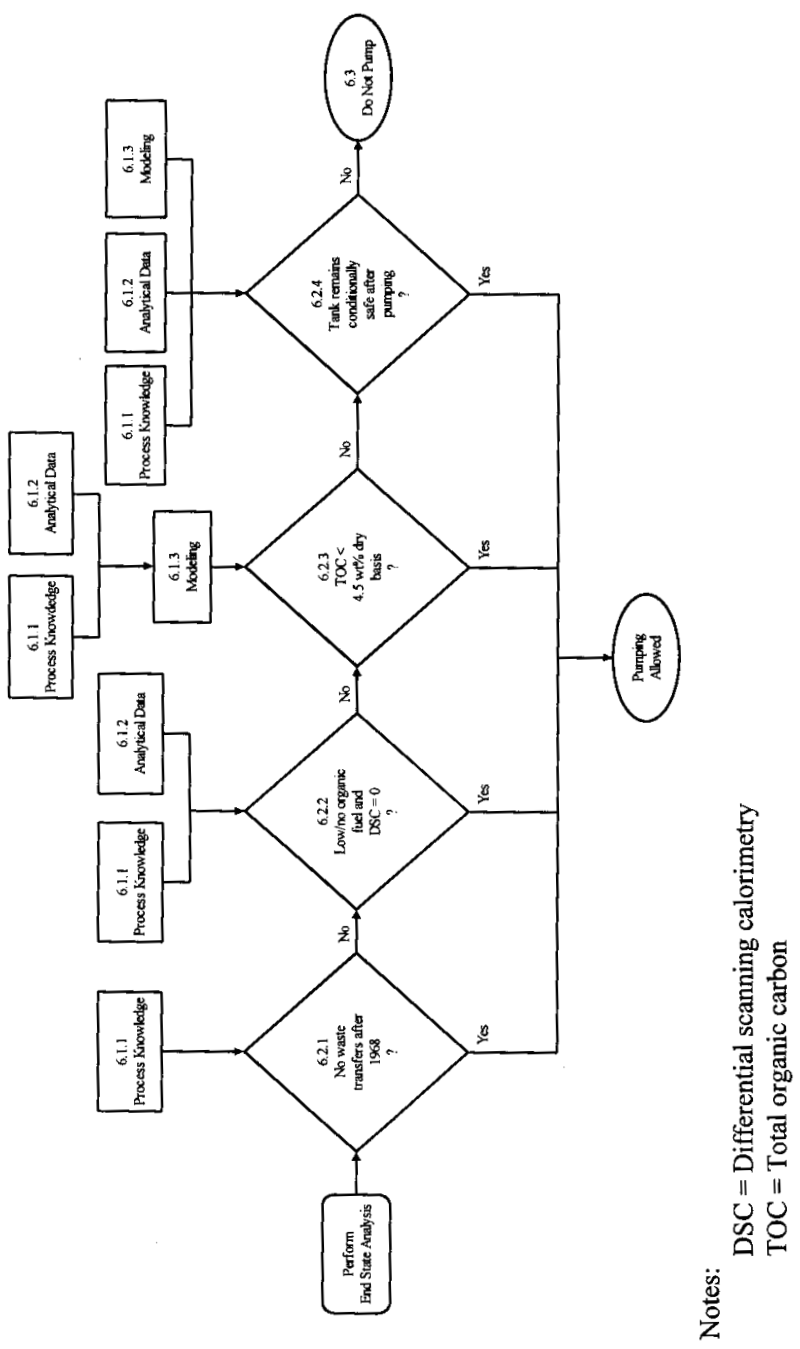




\subsection{RESULTS OF ANALYSIS}

Proceeding from left to right through the decision logic shown on Figure 1, a determination can be made as to whether saltwell pumping of tank $241-\mathrm{S}-103$ for interim stabilization will be allowed. The results of each step are presented in this section. The conclusion of this analysis is that tank $241-\mathrm{S}-103$ can be pumped because the tank will remain in the conditionally safe category after pumping. That determination is documented in this section.

\subsection{Criterion 6.2.1: No Waste Transfers After 1968}

Criterion 6.2.1 requires that there were no waste transfers into the tank after 1968 .

\section{Waste Transfer History}

- A description of the waste transfer history is taken from Homi (1996). Tank 241-S-103 started receiving waste from the Reduction Oxidation (REDOX) facility from the fourth quarter of 1953 until the fourth quarter of 1973. From the fourth quarter of 1973 until the second quarter of 1976, the tank received bottoms and recycle streams from the 242-S Evaporator. In the fourth uarter of 1976, the tank became a low-heat evaporator dump tank containing evaporator feed waste. Between the second quarter of 1978 and the fourth quarter of 1980, the tank ws classified as having non-complexed, partial neutralized feed and double-shell slurry feed wastes. From the first quarter of 1978 until the fourth quarter of 1980 , the tank received $\mathrm{HNO}_{3} / \mathrm{KMnO}_{4}$ solution. Tank $241-\mathrm{S}-103$ was removed from service in 1980 and was partially isolated in December 1982.

Criterion 6.2.1 is not satisfied because waste transfers into the tank occurred after 1968. The decision logic branch requires performance of criterion 6.2.2.

\subsection{Criterion 6.2.2: Low/No Organic and No Exotherms}

Criterion 6.2 .2 requires that the process history show the tank is expected to have no/low organic content (defined as the bulk waste possessing less than $0.53 \mathrm{wt} \%$ TOC) and that the differential scanning calorimetry (DSC) results show that there are no exotherms.

- The process history of tank 241-S-103 indicates that the waste is expected to meet the low/no organic fuel content criteria. Per Place and Pagedor (1998), the total inventory of TOC in tank $241-\mathrm{S}-103$ is estimated at $8,660 \mathrm{~kg}$. This mass of TOC is distributed through 939,000 liters of waste with an average bulk density of about 1.68. This results in a bulk TOC concentration of about $0.55 \mathrm{wt} \%$. Additionally, tank 241-S-103 samples reported in Fuller (1998) contained a maximum total organic carbon (TOC) content of $5220 \mathrm{ug} / \mathrm{mL}(0.76 \mathrm{wt} \%$ dry basis calculated using highest reported \% water $\{51.78 \%\}$ and lowest reported specific gravity $\{1.431\}$ ) for the September 1998 liquid grab sample. No values were reported for solids. These maximum values exceed the $0.53 \mathrm{wt} \%$ criterion. 
HNF-4364, Rev. 0

- For all analysis of the 241-S-103 waste, DSC results were reported a 0 Joules per gram. Therefore, none exceeded the 480 Joule per gram dry weight basis, action limit.

The conditions of criterion 6.2 .2 are exceeded. The decision logic branch requires performance of criterion 6.2.3.

\subsection{Criterion 6.2.3: TOC Less Tank 4.5 Weight Percent Dry Basis}

Criterion 6.2.3 requires that an analysis of variance (ANOVA) analysis using analytical data be used to determine whether the TOC in a tank is less than the limit of $4.5 \mathrm{wt} \%$ on a dry basis at the 95 percentile with a 95 percent confidence.

- A propagation analysis for all single-shell tanks is included in Meacham, et al., (1998). Results show that propagation is not possible in tank 241-S-103 because ANOVA extrapolation indicates low TOC concentrations.

A tank is considered to pass the ANOVA screening if the upper $95 \%$ bound dry combustible waste fraction of the tank is below 5\%. For tank 241-S-103 the upper 95\% dry combustible waste fraction is $4.8 \%$ (Meacham, et al., 1998). Therefore, Criterion 6.2 .3 is met, permitting pumping of liquid from the tank.

\subsection{CONCLUSION}

The organic end state analysis of tank $241-\mathrm{S}-103$ concludes that the tank can be pumped for interim stabilization. Saltwell pumping of the tank will not cause the waste in the tank to be categorized as unsafe. 


\subsection{REFERENCES}

Adams, M. R., 1999, Tank Waste Remediation System Process Engineering Instruction Manual, HNF-SD-WM-PROC-021, Rev. 2-A, Lockheed Martin Hanford Corp., Richland, Washington.

Fuller, K, 1998, Tank 241-S-103, Grab Samples, 3S-98-1, 3S-98-2, 3S-98-3 Analytical Results for the Final Report, HNF-1659, Rev. 0, Waste Management Hanford, Inc., Richland, Washington.

Hanlon, B. M., 1999, Waste Tank Summary Report for Month Ending January 31, 1999, HNF-EP-0182-130, Lockheed Martin Hanford Corp., Richland, Washington.

Homi, C. S., 1996, tank 241-S-103 Tank Characterization Plan, WHC-SD-WM-TI-387, Rev. 1, Westinghouse Hanford Company, Richland, Washington.

Meacham, J. E., W. L. Cowley, A. B. Webb, N. W. Kirch, J. A. Lechelt, D. A. Reynolds, L. A. Stauffer, D. B. Bechtold, D. M. Camaioni, F. Gao, R. T. Hallen, and P. G. Heasler, J. L. Huckaby, R. D. Scheele, C. S. Simmons, J. J. Toth, and L. M. Stock, 1998, Organic Complexant Topical Report: Final Draft, HNF-SD-WM-CN-058, Rev. 2, DE\&S Hanford, Inc., Richland, Washington.

Place, D. E., and M. Pagedọ, 1998, Preliminary Tank Characterization Report for Single-Shell Tank 241-S-103: Best-Basis Inventory, HNF-SD-WM-ER-688, Rev. 0A, COMEGA Engineering Corporation, Richland, Washington. 
HNF-4364, Rev. 0

\section{CHECKLIST FOR DOCUMENT REVIEW}

Document Reviewed: 4 NF -4364 Revision: 0

Scope of Review:

Yes No NA

BA [ ] [ ]

$\mathbb{X}][][]$

Q

[] [] $]$

[Q] [] []

QX] [] []

[][] $\boldsymbol{D}$

[][] $\mathrm{X}$

Q $[3][]$

[] []

[] []

XI] []

[ [ [ ] []

$\mathbb{M}[][]$

$\mathbb{D}[\mathrm{]}[\mathrm{]}$

$[1 \mathrm{k}] *$

[] [][]
Problem completely defined.

Appropriate analytical methods used.

Necessary assumptions explicitly stated and supported.

Computer codes and data files documented.

Data used in calculations explicitly stated in document.

Data checked for consistency with original source information as applicable.

Mathematical derivations checked including dimensional consistency of results.

Models appropriate and used within range of validity or use outside range of established validity justified.

Hand calculations checked for errors. Spreadsheet results should be treated exactly the same as hand calculations.

Software input correct and consistent with document reviewed.

Software output consistent with input and with results reported in document reviewed.

Limits/criteria/guidelines applied to analysis results are appropriate and referenced. Limits/criteria/guidelines checked against references.

Safety margins consistent with good engineering practices.

Conclusions consistent with analytical results and applicable limits.

Results and conclusions address all points required in the problem statement.

Review calculations, comments, and/or notes are attached.

Document approved.

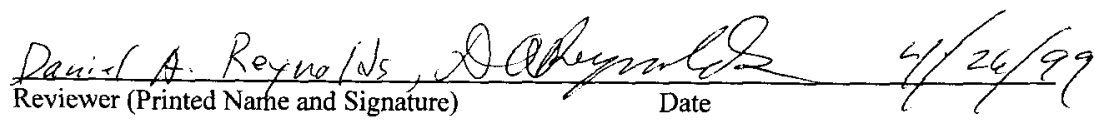

* Any calculations, comments, or notes generated as part of this review should be signed, dated and attached to this checklist. Such material should be labeled and recorded in such a manner as to be intelligible to a technically qualified third party. 
DISTRIBUTION SHEET

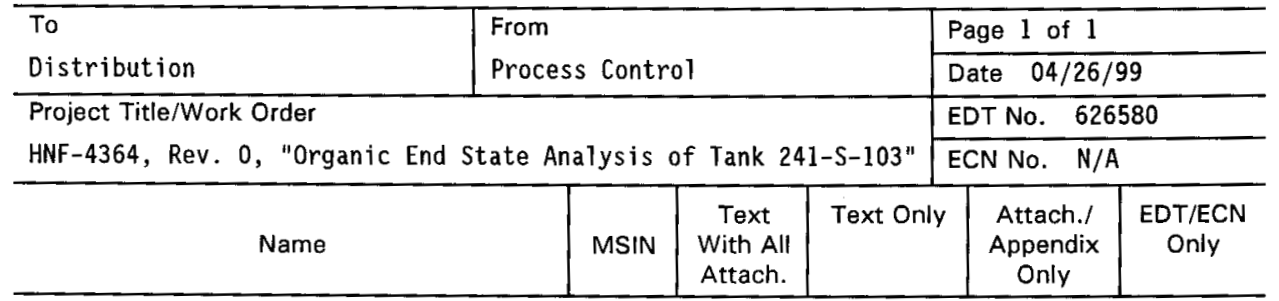

DE\&S Hanford, Inc.

J. E. Meacham

A. B. Webb

R1-49

$57-73$

$x$
$X$

Fluor Danie] Northwest

D. T. V1adimiroff

$57-20 \quad x$

Lockheed Mart in Hanford Corp.

R. P. Anantatmula

J. N. Doeler

J. G. Field

K. D. Fowler

K. M. Ha11

N. W. Kirch

M. R. Koch

D. A. Reynolds

D. J. Saueressig

TCSRC

R1-30

T4-07

$\mathrm{R} 2-12$

R2-11

R2-12

R2-11

S7-24

R2-11

S7-20

R1-10

$x$

Lockheed Martin Services, Inc.

Central Files

$x$
$x$
$x$
$x$
$x$
$x$
$x$
$x$
$x$
$x$ 